Андрушко А. В., кандидат юридичних наук, доцент, доцент кафедри крилінального права і процесу Ужгородського національного університету

\title{
ПРОБЛЕМИ КРИМІНАЛЬНОЇ ВІДПОВІДАЛЬНОСТІ ЗА ПІДМІНУ ДИТИНИ
}

\begin{abstract}
Анотація. У статті на підставі аналізу вітчизняного та зарубіжного законодавства і наукової літератури проаналізовано недоліки чинної редакції ст. 148 Кримінального кодексу України, яка передбачає відповідальність за підміну дитини, та запропоновано можливі шляхи іiі удосконалення.
\end{abstract}

Ключові слова: злочини проти волі, честі та гідності особи; злочини проти сім’ї та неповнолітніх, підміна дитини.

Постановка проблеми. Стаття 148 Кримінального кодексу України (далі - КК України) передбачає відповідальність за підміну дитини. У правозастосовній практиці цей злочин траплясться вкрай рідко. За даними МВС України, протягом 2002-2012 рр. зареєстровано всього 6 випадків вчинення даного діяння [1, с. 1]. За 2013 р. органами прокуратури обліковано 1 випадокпідміни дитини, у 2014 p. - 1, у 2015 p. - 0, у 2016 p. - 1, у 2017 р. - - 0, за 11 місяців 2018 р. - 2 таких злочини [2]. Таким чином, упродовж 2002-2018 рр. обліковано всього лише 11 випадків підміни дитини. Порівняння відповідних даних 3 кількісними показниками інших злочинів, відповідальність за які передбачена в розділі III Особливої частини КК України, дає підстави для висновку, що підміна дитини - найменш поширений з-поміж злочинів проти волі, честі та гідності особи. Надзвичайна рідкісність вказаного посягання у правозастосовній практиці дозволяс окремим дослідникам ставити питання про доцільність його декриміналізації [3, с. 195; 4, с. 110]. 3 такою точкою зору погодитись не можемо. Підміна дитини дійсно вкрай рідкісний, однак надзвичайно болючий для потерпілого злочин. Видається, що ст. 148 КК України виконує важливу превентивну функцію, а незначна кількість розглядуваних злочинів у даному випадку не дозволяє стверджувати про недоцільність та марність протидії їм. Крім того, варто мати на увазі високий рівень латентності підміни дітей [5, с. 19], який пов'язаний, зокрема, із недосконалістю у відповідній частині вітчизняного закону про кримінальну відповідальність.

Проблеми кримінальної відповідальності за підміну дитини аналізувалися в працях В.І. Борисова, Є.В. Даценка, Ю.Є. Пудовочкіна, I.О. Романчука, В.С. Савельєвої, М.І. Хавронюка, С.Д. Шапченка та інших науковців. Разом з тим більшість питань, пов'язаних з даною проблематикою, залишаються дискусійними та недостатньо дослідженими.

Мета статті - дослідити проблеми кримінальної відповідальності за підміну дитини та запропонувати можливі шляхи їх вирішення.

Виклад основного матеріалу дослідження. Для аналізу проблем кримінальної відповідальності за підміну дитини необхідно коротко охарактеризувати елементи складу цього злочину.

У спеціальній літературі немає єдності думок стосовно об'єкта аналізованого посягання. Так, на думку В.І. Борисова, безпосереднім об'єктом підміни дитини $є$ суспільні відносини, що забезпечують особисту недоторканність дитини та їі нормальний розвиток [6, с. 111; 7, с. 91]. На особисту недоторканність дитини як на об'єкт цього злочину вказує також Є.Л. Стрельцов [8, с. 280]. І.А. Вартилецька переконана, що особиста недоторканність дитини є основним безпосереднім об'єктом аналізованого діяння, а додатковим обов'язковим безпосереднім об'єктом - умови нормального формування та розвитку дитини, які ставляться під загрозу самим фактом відлучення ії від батьків [9, с. 340]. М.I. Хавронюк і Т.В. Варфоломеєва вважають, що об'єктом підміни дитини є особиста воля дитини та сім'я як блага, що охороняються Конституцією України [10, с. 368; 11, с. 382]. На думку Я.Г. Лизогуба, основним безпосереднім об'єктом цього злочину є воля людини [12, с. 114]. Є.В. Даценко переконаний, що безпосереднім об'єктом цього злочину є суспільні відносини, які виникають у зв'язку з існуванням і реалізацією прав дітей та батьків на дитинство і батьківство $[1$, с. 9].

Відзначимо, що у вітчизняному кримінальному законодавстві стаття про відповідальність за підміну дитини міститься в розділі, що об'єднує злочинні посягання проти волі, честі та гідності особи. Такий же підхід має місце в КК Туркменістану. Натомість у законодавстві більшості держав стаття про відповідальність за вказане діяння міститься в главі (або розділі), що об'єднує злочинні посягання проти сім'ї та неповнолітніх [13, с. 100]. Відповідний розділ в КК України взагалі відсутній. У зв'язку з цим в науковій літературі неодноразово пропонувалося виокремити такий розділ в структурі Особливої частини вітчизняного кримінального закону $[1$, с. 9; 14 , c. $6,11-12,14 ; 15$, с. $199 ; 16 ; 17$, с. 252-253], а також перенести до нього статті про відповідальність за відповідні злочини, в т.ч. й ст. 148 КК України [1, с. 9; 14, с. 11, 14; 15, с. 199; 17 , с. $253 ; 18$, с. 99]. На переконання В.В. Гальцової, існуючий у чинному кримінальному законодавстві підхід до вирішення питань кримінально-правової охорони сім'ї, прав та законних інтересів неповнолітніх і місця цих норм у системі Особливої частини КК України навряд чи можна визнати досконалим, оскільки він не забезпечує необхідного комплексного кримінально-правового захисту сім'ї та неповнолітніх [18, с. 99]. Разом 3 тим, як видається, має рацію 0.О. Дудоров, який підкреслює, що рівень захисту того чи іншого об’єкта кримінально-правової охорони визначається не місцем тієі чи іншої заборони у системі кримінального закону, а тим, наскільки ця заборона якісно сформульована та ефективно застосовується [19, с. 37]. Таким чином, не заперечуючи жодним чином необхідності належної кримінально-правової охорони сім'ї та інтересів неповнолітніх, не можемо, однак, погодитись 3 тим, що надійність та ефективність такої охорони страждають передовсім через відсутність 
в структурі Особливої частини КК України розділу, в якому було 6 акумульовано всі злочини проти сім'ї та неповнолітніх. Варто звернути увагу на те, що прихильники виокремлення відповідного розділу не можуть дійти згоди з приводу злочинів, які мають увійти до нього [16, с. 76-79]. Це й не дивно, адже зрозуміло, що фактично будь-який злочин, потерпілим від якого є дитина (ті ж вбивство, згвалтування, крадіжка, грабіж тощо), посягає на інтереси неповнолітнього. У розглядуваному контексті можна погодитись з I.О. Бандуркою, яка відзначає, що захист дитинства у чинному КК України має комплексний, системний і наскрізний характер від посягань на різного роду об'єкти злочинів, що охороняються різними відповідними розділами Особливої частини КК України [20, с. 399].

Точка зору вітчизняного законодавця, який статтю про відповідальність за розглядуване діяння розмістив у розділі III Особливої частини КК України, не видається нам помилковою. Питання в тому, які цінності законодавець насамперед хотів поставити під кримінально-правову охорону в межах певного розділу. Не варто забувати, що право на свободу є невід'ємним природним правом кожної людини, яке належить їй від народження. Зрозуміло, що зважаючи на об'єктивні причини, дитина у повному обсязі не володіє свободою, іiі вчинки, як правило, контролюються батьками чи іншими особами, на яких покладені обов'язки по іiї вихованню та розвитку. Це, однак, не заперечує того, що при підміні дитини відбувається посягання на її особисту свободу. Крім цього, на наш погляд, через відділення дитини від батьків страждає іiі гідність, пов'язана 3 правом перебувати, рости і виховуватись в своїй сім'ї, а також з правом на збереження своєї індивідуальності, яка, як видається, є невід'ємною складовою гідності. Одним із базових принципів, закріплених в Декларації прав дитини 1959 р., є положення про те, що «дитині законом та іншими засобами має бути забезпечений спеціальний захист і надані можливості та сприятливі умови, що дадуть ій змогу розвиватися фізично, розумово, морально, духовно та соціально, здоровим і нормальним шляхом, в умовах свободи та гідності». В Законі України «Про охорону дитинства» (ст. 10) вказується, що кожній дитині гарантується право на свободу, особисту недоторканність та захист гідності. Точка зору про те, що основним безпосереднім об'єктом розглядуваного злочину $€$ особиста свобода та гідність дитини, на наш погляд, зовсім не заперечує того, що це діяння посягає на передбачене Конституцією України право людини на дитинство, материнство чи батьківство, що, як видається, є очевидним. Більше того, в результаті підміни дитини страждає цілий комплекс іiі природних прав, гарантованих міжнародним та національним законодавством. Так, Конвенція ООН про права дитини 1989 р. встановлює, що кожна дитина 3 моменту народження має право на ім'я і набуття громадянства, право знати своїх батьків і право на їх піклування (ст. 7), право на збереження індивідуальності, включаючи громадянство, ім'я та сімейні зв'язки (ст. 8), право не розлучатися з батьками і підтримувати на регулярній основі особисті відносини і прямі контакти з обома батьками (ст. 9). Ю.Є. Пудовочкін слушно підкреслює, що блокуючи задоволення вказаних прав, підміна перешкоджає повнокровному процесу формування особистості дитини, виключає важливу складову ії приватного життя, пов'язану з сімейними відносинами, збіднює духовне життя, нерідко порушує майнові та фізичні інтереси дитини [21, с. 43]. Цей злочин може завдати дитині або навіть уже дорослій людині, котра в дитинстві була підмінена, серйозну психологічну травму.
Через усвідомлення того, що їх справжня дитина була від них відторгнута, і що вони виховували чужу дитину, значна психічна шкода може бути завдана й батькам дитини чи особам, що їх замінюють. У зв'язку із викладеним можна зробити висновок, що потерпілими від цього злочину слід визнавати не тільки підмінених дітей, а й їхніх батьків (осіб, що їх замінюють).

Не можемо погодитись 3 тими авторами, які підмінених дітей називають предметом розглядуваного злочину [8, с. 280; 22, c. 55]. На наш погляд, цей злочин, так само, як і інші злочини, де потерпілим в кримінально-правовому сенсі виступає людина, слід відносити до безпредметних. Має рацію Я.Г. Лизогуб, який відзначає, що на тлі зростання ціннісної оцінки людини іменування іiі предметом злочину є неприпустимим, адже в такому випадку людина наділяється ознаками предмета, речі [12, с. 115].

Однією із найдискусійніших в юридичній літературі є проблема граничного віку потерпілої від цього злочину дитини. Одразу зауважимо: у всіх проаналізованих нами випадках, що мали місце в об'єктивній дійсності, йшлося про підміну новонародженої дитини [5, с. 20]. Цей факт, однак, не позбавляє необхідності з'ясувати вік, досягнення якого виключає можливість стати потерпілою від розглядуваного діяння.

Відповідаючи на питання про те, до досягнення якого віку можлива підміна дитини, науковці розділилися. Більшість дослідників відзначає, що підміна може бути вчинена лише щодо новонародженої (як варіант - новонародженої або грудної) дитини $[11$, с. $383 ; 23$, с. $28 ; 24$, с. 10,$23 ; 25$, с. 8,16 ; 26, с. 9, 18]. Свою точку зору детально пояснює К.М. Почивалова, котра підкреслює, що під дитиною у цій статті слід розуміти саме новонароджену дитину, оскільки період, коли батьки не мають можливості помітити заміну, дуже незначний; він може бути пов'язаний або з неможливістю батьків ідентифікувати свою дитину на ранніх періодах іiі життя, або із знаходженням матері дитини в тяжкому стані в післяпологовий чи наступний за ним період, у зв'язку з чим вона позбавлена можливості спілкування зі своєю дитиною [24, с. 10, 23]. Відзначимо, що окремі автори пропонують відобразити таку свою позицію в кримінальному законі. Так, К.Є. Пухтій переконана, що оскільки потерпілою від цього злочину може бути лише новонароджена дитина, то в диспозиції потрібно конкретизувати, що підміна можлива тільки щодо такої дитини $[25$, с. 8,16$]$. Подібну точку зору відстоює Н.В. Гуль, яка пропонує: а) назвати відповідну статтю «Підміна новонародженої дитини»; б) в диспозиції вказати на те, що підміна може бути вчинена лише щодо новонародженої дитини; в) роз'яснити в тексті кримінального закону, кого слід розуміти під новонародженою дитиною (на ії думку, новонародженою є дитина до досягнення нею одного місяця) [26, с. 9, 18]. У той же час слід звернути увагу на те, що, встановлюючи кримінальну відповідальність за умисне вбивство матір'ю своєї новонародженої дитини, у ст. 117 КК України законодавець чітко вказав на те, що потерпіла дитина $€$ новонародженою; у розглядуваній статті законодавець відмовився від такого уточнення.

Інші науковці висловлюються менш категорично, вказуючи, що під дитиною у цій статті слід розуміти, як правило, новонароджене чи грудне немовля $[6$, с. $111 ; 7$, с. 91 ; 10 , с. 368 ; 27, с. 99]. При цьому М.I. Хавронюк уточнює свою позицію, зазначаючи, що мова тут має йти, як правило, про немовля особу, ідентифікувати яку за їі індивідуальними ознаками бать- 
ки чи інші законні представники з певних причин ще повною мірою неспроможні (скажімо, підміна відбулася до того, як мати здатна була запам'ятати щойно народжену дитину, або до передачі дитини батькові у разі смерті матері тощо) [10, с. 368].

На переконання третьої групи дослідників проблеми, розглядуване діяння може бути вчинене й щодо дитини більш старшого віку. Так, наприклад, М.Й. Коржанський був переконаний, що потерпілою від цього злочину слід визнавати малолітню особу, якій не виповнилося ще 14 років [28, с. 172]. B.I. Ткаченко вважав, що при визначенні віку, до досягнення якого можлива підміна дитини, слід відштовхуватись від іiі дієздатності, у зв'язку з чим граничним віком потерпілої від цього злочину дитини вважав 15 років [29, с. 75].

Ще одна група науковців вважає, що під дитиною тут потрібно розуміти особу, якій на момент вчинення щодо неї злочину не виповнилось 18 років [12, с. $114 ; 21$, с. $43 ; 30$, с. 281 ; 31, c. $216-219 ; 32$, с. $16 ; 33$, с. 12]. Відповідна точка зору узгоджується із міжнародним та національним законодавством. Так, у ст. 1 Конвенції ООН про права дитини вказано, що дитиною є кожна людська істота до досягнення 18-річного віку, якщо за законом, застосовуваним до даної особи, вона не досягає повноліття раніше. В ч. 1 ст. 6 Сімейного кодексу України зазначено, що правовий статус дитини має особа до досягнення нею повноліття. Закон України «Про охорону дитинства» (ст. 1) також виходить 3 того, що дитина - це особа віком до 18 років (повноліття), якщо згідно з законом, застосовуваним до неї, вона не набуває прав повнолітньої раніше. Водночас у розглядуваному контексті необхідно чітко дати відповідь на питання про те, чи можливе взагалі вчинення аналізованого злочину стосовно особи у віці до 18 років. Одним із перших, хто висловив думку про те, що підміна дитини можлива не тільки щодо новонародженого чи грудного немовляти, а й стосовно дитини старшого віку, був О.В. Лохвицький, який ще у 1871 році писав, що якщо, для прикладу, дитина 3 дня народження була віддана іншій жінці-годувальниці, то підміна можлива до того часу, поки мати не ознайомиться 3 дитиною, або ж дитина не усвідомить свого походження [34, с. 515]. Через 130 років, у 2001 році, Ю.С. Пудовочкін слушно відзначив, що в сучасних умовах не можна виключити аналогічної ситуації. Припустимо, що відразу після народження дитини мати відмовиться від неї. Дитина потрапляє в дитячий будинок чи в інший виховний заклад і не знає свого справжнього походження. Якщо через кілька років мати вирішить знайти свою дитину і турбуватися про неї, хто гарантує, що її не можна буде підмінити? У зв'язку з цим вказаний автор робить висновок, що підміна можлива щодо будь-якої особи, яка не досягла 18 років і не усвідомлювала свого походження, за умови, що й батьки не були 3 ним ознайомлені [21, с. 43].

На наш погляд, наведені аргументи дозволяють підтримати точку зору останньої групи вчених. Дійсно, не можна повністю виключити ситуацій, коли одразу після пологів мати та немовля розділяються і через роки батьків (чи осіб, що їх замінюють) фактично наново знайомлять 3 дитиною, що ії видають за їхню; підміну в такому разі виключати не можна. Видається, що не слід безпідставно звужувати поняття «дитина» (зокрема, шляхом вказівки в диспозиції ст. 148 КК України, що йдеться виключно про підміну новонародженої дитини), котре, як зазначалося вище, добре відоме як міжнародному, так і національному законодавству. У той же час слід підкреслити, що, на нашу думку, при кваліфікації розглядуваного посягання значення має не стільки вік потерпілої від цього злочину особи, скільки здатність ідентифікувати себе в якості дитини конкретних батьків, а також здатність батьків (осіб, що їх замінюють) ідентифікувати дитину як свою. Якщо така здатність наявна, підміна дитини неможлива.

У назві ст. 148 КК України та тексті їі диспозиції йдеться про підміну дитини. Насправді ж при вчиненні цього злочину підмінюються дві дитини, а не одна: підмінювана дитина та дитина, що використовується для підміни. На цей факт уже зверталася увага в спеціальній літературі, у зв'язку з чим пропонувалося змінити назву відповідної статті на «Підміна дітей», а також наголошувалось на необхідності вказівки на множину підмінюваних дітей в їі диспозиції [33, с. 10; 35, с. 9]. Вважаємо, що використання словосполучення «підміна дітей» не можна визнати коректним, оскільки воно є двозначним і надто широким за змістом (так само, до речі, як і вказівка на множину потерпілих у назві ст.ст. 147, 149, 150 КК України). На наш погляд, назву ст. 148 КК України доцільно сформулювати як «Підміна однієї дитини іншою»; вказаний момент слід відобразити також у диспозиції даної статті.

У диспозиції ст. 148 КК України законодавець уточнює, що відповідальність настає за підміну чужої дитини. Серед проаналізованих нами 23 кримінальних законів, що передбачають відповідальність за розглядуване діяння, аналогічне уточнення міститься тільки в ст. 172 КК Азербайджанської Республіки та ч. 1 ст. 174 Пенітенціарного кодексу Естонської Республіки. Вочевидь, зроблено воно для вказівки на відсутність родинних зв'язків між дитиною та суб'єктом даного злочину. Разом 3 тим, зважаючи на викладене вище, із наявного в диспозиції ст. 148 КК України формулювання не зрозуміло, котра саме дитина є чужою для винного - підмінювана, чи та, що використовується для підміни. 3 огляду на сказане, у тексті аналізованої норми слід уточнити, що відповідальність настає за підміну чужої дитини іншою чужою або своєю дитиною. Відзначимо, що подібне формулювання міститься в ч. 1 ст. 174 Пенітенціарного кодексу Естонської Республіки.

Об'єктивна сторона розглядуваного злочину полягає у підміні чужої дитини іншою чужою або своєю дитиною. У Великому тлумачному словнику сучасної української мови вказується, що підміна означає «дію, за якої один предмет, одне явище підмінюють іншим, одна особа виступає замість іншої» [36, с. 958]. I.А. Вартилецька вважає, що розглядуваний злочин може бути вчинений у таких випадках: 1) при заміні своєї дитини (наприклад, хворої, із зовнішністю представника неєвропейської раси тощо) на чужу; 2) при заміні чужої дитини на чужу [9, с. 340; 27, с. 99]. На наш погляд, можлива не тільки заміна своєї дитини на чужу, а й чужої дитини на свою. Крім того, не можемо погодитись з Т.В. Варфоломеєвою, яка, підкресливши, що акт підміни у будь-якому разі передбачає участь двох дітей, яких міняють місцями, вважає, що «видавання якоїсь дитини за іншу не може кваліфікуватися за ст. 148, а за певних обставин і умов (мета, мотив, спосіб) кваліфікуватиметься як шахрайство» $[11$, с. 383]. По-перше, вважаємо, що заміна дітей в таких випадках все-таки має місце (наприклад, чужа мертва дитина медичним працівником пологового будинку видається матері як її біологічна дитина замість народженої живої), хоча вона й характеризується певними особливостями. По-друге, видавання однієї дитини за іншу є суттю розглядуваного злочину, 
оскільки відповідні дії особи є обманними за самою своєю природою (дії суб'єкта спрямовані на те, аби створити хибне враження у батьків дитини та в інших осіб, що в дійсності підміни не відбулося). По-третє, жодних підстав для того, аби кваліфікувати відповідне діяння як шахрайство немає, адже шахрайство полягає в заволодінні чужим майном або придбанні права на майно шляхом обману чи зловживання довірою. Дитина, звісно, не може слугувати майном чи правом на майно.

Підміна однієї дитини іншою відбувається шляхом активної дії, що фактично є загальновизнаним у доктрині кримінального права. Разом з тим в юридичній літературі висловлювалося припущення, що вчинення цього злочину можливе і шляхом бездіяльності [21, с. 43]. Ю.Є. Пудовочкін моделює ситуацію, коли підміна дитини вчиняється шляхом бездіяльності: у випадку, якщо батьки чи інші особи, які усвідомлюють факт підміни і зобов'язані йому перешкодити в силу професійної приналежності, не протидіють особам, що вчиняють підміну, однак не усвідомлюють її (наприклад, мати не перешкоджає діям медсестри пологового будинку, котра міняє дітей через недбалість) $[21$, с. 43]. Не виключаючи повністю такої можливості, все ж відзначимо, що імовірність ситуаціі, при якій бажання підмінити одну дитину іншою співпадає з необережними діями незацікавленої особи, є надзвичайно низькою [37, с. 91].

Не можемо погодитись 3 тими авторами, які вважають, що об'єктивна сторона аналізованого діяння полягає у вилученні дитини в батьків чи в осіб, що їх замінюють, і залишенні їм іншої, чужої дитини [29, с. 75; 38, с. 140]. Насправді вилучення дитини в батьків (законних представників) у власному сенсі цього слова може й не відбуватися (для прикладу, особа з хуліганських спонукань чи з мотивів помсти у пологовому будинку замінює чужих для неї дітей в період, коли їхні матері не перебувають 3 ними, або ж особа міняє місцями бирки на немовлятах в пологовому будинку).

Важливе значення для об'єктивної сторони цього злочинного діяння має спосіб його вчинення. В юридичній літературі здебільшого вказується, що розглядуваний злочин вчиняється таємно [21, c. $44 ; 32$, с. $17 ; 33$, с. 5 ; 37 , с. 90 ; 39, с. $188 ; 40$, с. $109-111]$. Натомість В.І. Ткаченко стверджує, що підміна дитини, як і ïi викрадення, може бути вчинена не тільки таємно, а й відкрито, в т.ч. й шляхом застосування насильства [29, с. 75]. На наш погляд, теоретично цей злочин може бути вчинений не лише таємним, але й відкритим способом: наприклад, винний вчиняє підміну в присутності сторонньої особи, яка усвідомлює це, не $€$ співучасником, але й не перешкоджає вчинюваному злочину. Ймовірність такої ситуації, звісно, мінімальна, однак повністю виключити iї не можна. Водночас можна однозначно стверджувати про те, що, підмінюючи одну дитину іншою, суб'єкт злочину намагається вчинити діяння таким чином, щоб про нього не дізналися батьки дитини, тобто підміна обов'язково вчиняється таємно для батьків дитини. Ю.Є. Пудовочкін відзначає, що таємність підміни може мати місце в тих ситуаціях, коли: 1) батьки обох дітей не усвідомлюють, що відбулася їх підміна; у цьому випадку підміну здійснила особа, яка не є батьком чи матір'ю дитини; 2) батьки однієї дитини не усвідомлюють факту підміни, вчинюваної батьками іншої дитини; 3) мати (батько) однієї дитини, не повідомляючи про це їі батька (матір), вчиняє підміну цієї дитини на іншу [21, с. 44].

Можливим способом підміни дитини є також обман: винні можуть поміняти хвору дитину на здорову, живу - на мертву
[33, с. 5; 40, с. 111]. Відзначимо, що ситуація, коли відбувається заміна народженої живої дитини на чужу мертву, яка й видається як біологічна дитина матері, $є$ найпоширенішою на практиці [5, с. 18$]$.

На думку Є.В. Даценка, всі можливі способи підміни дитини можуть бути класифіковані на три групи: 1) фізичне переміщення дітей у просторі; 2) заміна, підроблення, знищення, пошкодження, викрадення, приховування засобів ідентифікаціі; 3) «змішані» способи, коли відбувається фізичне переміщення дитини в просторі, а також заміна, підроблення, знищення, пошкодження, викрадення, приховання засобів ідентифікації $[1$, c. 9]. Цей автор відзначає, що у чотирьох з шести вивчених ним кримінальних проваджень підміна дитини була вчинена «змішаним» способом, у двох випадках - шляхом фізичного переміщення. Водночас такі дані не підтверджуються результатами проведеного нами дослідження, яке, повторимось, засвідчило, що в абсолютній більшості проаналізованих випадків мала місце ситуація видання матері (після того, як породілля відходила від анестезії) чужої мертвої дитини за нібито народжену нею.

У юридичній літературі загальновизнаним є те, що розглядуваний склад злочину є формальним, а тому його слід вважати закінченим з моменту підміни однісї дитини іншою. У цьому зв'язку вирізняється позиція Є.В. Даценка, який переконаний, що об'єктивна сторона цього злочину характеризується трьома обов'язковими ознаками: 1) дія, спрямована на підміну дитини; 2) суспільно небезпечні наслідки у вигляді «переходу» дітей від законних батьків (усиновителів, опікунів) до інших; 3) причинний зв'язок між дією та суспільно небезпечним наслідком. Моментом закінчення підміни дитини Є.В. Даценко пропонує визнавати момент настання суспільно небезпечних наслідків у вигляді «переходу» дитини від законних батьків (усиновителів, опікунів) до інших - незаконних [1, с. 5, 9, 14]. Точку зору цього науковця не можна визнати обгрунтованою, оскільки законодавець говорить тільки про підміну дитини (вказує на діяння), залишаючи наслідки поза межами аналізованого складу злочину.

Як відзначалося вище, на переконання більшості дослідників, цей злочин є закінченим з моменту вчинення підміни чужої дитини $[6$, с. $111 ; 7$, с. $91 ; 9$, с. $340 ; 21$, с. $43 ; 30$, с. $281 ; 33$, с. 4; 35, с. 19]. Водночас окремі науковці намагаються уточнити цей момент. Так, на думку В.Б. Хатуєва, «закінченим цей злочин вважатиметься 3 моменту підміни, тобто коли винний заволодів дитиною і передав (поклав) замість неї іншу, що дозволяє йому розпорядитися першою» [38, с. 140]. Насправді, зрозуміло, заволодіння дитиною при ії підміні відбувається не завжди; для прикладу, винний просто може поміняти місцями бирки на немовлятах в пологовому будинку. Є.Л. Стрельцов вважає, що підміна дитини є закінченою, наприклад, коли матері передають чужу дитину, з моменту внесення відповідного запису у книгу обліку в пологовому будинку тощо [8, с. 280]. 3 такою точкою зору також погодитись не можемо, оскільки фактична підміна однієї дитини іншою на той момент, що його вказує Є.Л. Стрельцов, вже відбулася. На думку О.С. Колмакової, цей злочин $є$ закінченим, коли батьки підмінених дітей, не помітивши підміни, сприйняли їх як своїх [37, с. 90]. Відповідна позиція також видається хибною, оскільки, як слушно зазначає С.Д. Шапченко, помилкове сприйняття дитини як своєї з боку іiі батьків чи інших законних представників не є обов'язковою ознакою цього злочину [30, с. 281]. Крім того, точка зору О.С. Колмакової видається хибною й тому, що про факт 
підміни однієї дитини іншою нерідко можна дізнатися тільки якщо ця підміна з'ясується батьками, котрі, на думку вказаного автора, якраз не мають помітити іiі. Цікаву й оригінальну думку висловив А.Р. Акієв, на переконання якого досліджуваний злочин слід визнавати триваючим, оскільки увесь період, протягом якого діти розлучені зі своїми батьками, продовжується порушення як прав дітей на виховання своїми батьками, на їх турботу, на спільне з ними проживання, так і прав батьків виховувати своїх дітей, не розлучатися з ними всупереч своїй волі, не інакше як за рішенням суду [32, с. 8, 16-17; 40, с. 104-106]. 3 цією точкою зору також не погоджуємось, оскільки у нашому випадку не можна говорити про обов'язкове для характеристики триваючих злочинів [41, с. 72, 74, 81, 92, 98] безперервне вчинення винним розглядуваного злочину (законодавець вказує лише на підміну дитини, що є одноразовою дією). Видається, що у своїх судженнях А.Р. Акієв повністю переносить акцент із суспільно небезпечного діяння на можливі суспільно небезпечні наслідки аналізованого злочину, які, за задумом законодавця, не є обов'язковою ознакою об'єктивної сторони складу підміни дитини. Таким чином, розглядуваний злочин слід визнавати закінченим з моменту підміни однієї дитини іншою. Діяльність, спрямована на підміну дитини, яка, однак, не привела до цього $з$ причин, що не залежали від волі винного, утворює замах на цей злочин.

Суб'єктом досліджуваного злочину є фізична осудна особа, якій на момент вчинення злочину виповнилось 16 років та яка є юридично чужою для потерпілого. Суб' єктами підміни дитини на практиці можуть бути батьки, персонал пологових будинків, працівники виховних та інших дитячих закладів, інші зацікавлені особи. Відзначимо, що згідно з даними, отриманими як нами [5, с. 19], так і іншими дослідниками [39, с. 189; 40, с. 123-124; 42, с. 35], цей злочин здебільшого вчиняють медичні працівники пологового будинку, які в силу своїх функціональних обов'язків відповідають за ідентифікацію та охорону дитини. При цьому Д.Л. Гулякевич слушно вказує на те, що прирівнювати статус цих осіб стосовно відповідальності за підміну дитини до статусу інших осіб навряд чи правильно. Жінка, що перебуває в пологовому будинку, має відчувати себе в безпеці і бути впевненою в безпеці своєї дитини, за яку відповідають саме медичні працівники [39, с. 189-190; 42, с. 35]. Як видається, є всі підстави для висновку, що підміна однієї дитини іншою, вчинена особою з використанням свого службового становища чи при виконанні професійних обов'язків, характеризується більшим ступенем суспільної небезпеки, ніж підміна дитини, вчинена загальним суб'єктом. У зв'язку з цим вважаємо, що в межах ст. 148 КК України доцільно виокремити частину 2, в якій передбачити посилену відповідальність за підміну однієї дитини іншою, вчинену службовою особою з використанням службового становища, або особою при виконанні своїх професійних обов'язків. Відзначимо, що аналогічний висновок зроблений також деякими іншими науковцями [24, c. 11,$24 ; 39$, с. $190 ; 40$, c. $126 ; 42$, с. 35$]$.

Суб'єктивна сторона розглядуваного злочину характеризується прямим умислом і корисливими або іншими особистими мотивами. Вказівка в диспозиції ст. 148 КК України на корисливі або інші особисті мотиви виключає необережну форму вини в аналізованому злочині. Більше того, з огляду на те, що склад злочину сконструйований законодавцем як формальний, умисел тут може бути лише прямим. Вчиняючи це діяння, осо- ба усвідомлює, що підміняє одну дитину іншою і бажає цього. Точка зору Є.В. Даценка, який в одній із публікацій пише про різне ставлення винного до діяння (прямий або непрямий умисел) та його наслідків (злочинна самовпевненість та злочинна недбалість) [43, с. 67-68], є надуманою і такою, що не відповідає положенням кримінального закону. У зв'язку з цим вважаємо, що вона не потребує аналізу. Більше того, згодом Є.В. Даценко змінив свою точку зору, вказавши, що суб'єктивна сторона підміни дитини характеризується прямим умислом [1, с. 11, 15].

Обов'язковою ознакою суб' єктивної сторони розглядуваного злочину є корисливі або інші особисті мотиви. Корисливі мотиви полягають у прагненні винного до збагачення, означають, що суб'єкт злочину прагне одержати внаслідок підміни чужої дитини матеріальну вигоду у будь-якій формі або ж позбутися матеріальних витрат. Інші особисті мотиви можуть бути низькими (помста, ревнощі, заздрість тощо) або благородними (приміром, підміна приреченої на смерть тяжко хворої дитини в інтересах їі матері на здорову дитину, від якої відмовилась мати останньої). На наш погляд, варто погодитись з М.І. Хавронюком, який вважає, що в другому випадку, зважаючи на надзвичайно специфічний етичний бік справи, може йтися про відсутність суспільної небезпеки діяння через малозначність [10, с. 369].

У юридичній літературі неодноразово зверталася увага на недоцільність вказівки у диспозиції досліджуваної статті на мотиви вчинення підміни дитини. Так, Г.А. Решетнікова слушно вказує на те, що законодавець відзначає особливості мотиву злочину передовсім у тих випадках, якщо з цими особливостями безпосередньо пов' язане визначення суспільної небезпеки злочинного діяння; інакше кажучи, коли в цих особливостях виражається основна властивість діяння, його суспільна небезпечність. У зв'язку з цим вона ставить запитання: чи стає це діяння злочинним тільки тому, що особа, яка його вчиняє, керується корисливими або іншими мотивами? Відповідь однозначна: ні. У зв'язку з цим, на іiі думку, критерієм криміналізації тут мають бути не певні мотиви, а саме діяння - підміна дитини [44, c. 11, 30-31]. Подібні аргументи наводять також А.Р. Акієв $[32$, с. 8, 19; 40, с. 143-145], Н.В. Гуль [26, с. 9-10, 18], Д.Л. Гулякевич [39, с. 191; 42, с. 35-36], Є.В. Даценко [1, с. 11] та інші науковці. На наше переконання, злочинною має визнаватись будь-яка підміна чужої дитини, незалежно від мотивів. У зв'язку із цим вважаємо за доцільне відмовитись від вказівки в диспозиції ст. 148 КК України на корисливі або інші особисті мотиви. В той же час варто погодитись з Є.В. Даценком, який пропонує посилити відповідальність за підміну дитини, вчинену з корисливих мотивів $[1$, с. 11, 15, 16]. На наш погляд, підвищений ступінь суспільної небезпеки підміни дитини, вчиненої 3 корисливих мотивів, пов'язаний з морально-психологічною деформацією особистості суб'єкта такого злочину, з грубим порушенням ним важливих прав інших осіб заради задоволення власних матеріальних потреб. Натомість доповнювати розглядувану статтю такою кваліфікуючою ознакою, як вчинення підміни дитини з інших особистих мотивів, що іiі також пропонує вказаний автор, потреби немає, оскільки, на наш погляд, відповідні мотиви мають місце в будь-якому випадку.

Окрім вказаних кваліфікуючих ознак, у науковій літературі пропонувалися й інші можливі обставини, що обтяжують кримінальну відповідальність за підміну дитини. На думку вчених, існує потреба посилити кримінальну відповідальність за підміну дитини, вчинену: щодо двох або більше 
осіб [25, с. 23; 33, с. 12], за попередньою змовою групою осіб [1, c. 11,$16 ; 25$, c. $23 ; 33$, с. 12], організованою групою [25, с. 23 ; 33, c. 12], з метою вилучення частин тіла або тканин дитини для трансплантації [42, с. 36]. На жаль, належне обгрунтування відповідних пропозицій у їх авторів відсутнє. Зважаючи на фактичну відсутність в об' єктивній дійсності випадків підміни дитини, вчиненої за наявності відповідних обставин, доцільність доповнення ст. 148 КК України наведеними кваліфікуючими ознаками на сьогодні видається сумнівною.

Висновки. На підставі викладеного вище можемо запропонувати нову редакцію статті 148 КК України:

«Стаття 148. Підміна однієї дитини іншою

1. Умисна підміна чужої дитини іншою чужою або своєю дитиною, -

карається...

2. Те саме діяння, вчинене з корисливих мотивів, або службовою особою з використанням службового становища, або особою при виконанні своїх професійних обов'язків, -

карається...».

\section{Jimepamypa:}

1. Даценко Є.В. Кримінально-правова характеристика підміни дитини: автореф. дис. ... канд. юрид. наук: 12.00.08. Київ, 2015. 20 с.

2. Статистична інформація про заресстровані кримінальні правопорушення та результати їх досудового розслідування за 2013-2018 pp. // Офіційний сайт Генеральної прокуратури України. URL: http://www.gp.gov.ua/ua/stat.html

3. Лісняк С.Г. Кримінологічна характеристика злочинів проти волі, честі та гідності особи (2010-2014 роки). Вісник Запорізького національного університету. Юридичні науки. 2015. № 1 (II). С. 188-195.

4. Моніторинговий кримінологічний аналіз окремих видів злочинів в Україні (2013-2014 роки): наук.-практ. посіб. / О.М. Литвак, Р.О. Стефанчук, Н.В. Лісова та ін. Київ: Національна академія прокуратури України, 2015. 254 с.

5. Андрушко А. Підміна дітей: кримінологічна характеристика та напрями запобігання. Visegrad journal on human rights. 2018. № 5 (volume 1). C. 17-22.

6. Кримінальний кодекс України. Науково-практичний коментар: у 2 т. Т. 2: Особлива частина / за заг. ред. В.Я. Тація, В.П. Пшонки, В.І. Борисова, В.І. Тютюгіна. Харків: Право, 2013. 1040 с.

7. Кримінальне право України: Особлива частина: підручник / за ред. проф. В.Я. Тація, В.І. Борисова, В.І. Тютюгіна. Харків: Право, 2015. $680 \mathrm{c}$.

8. Кримінальний кодекс України: науково-практичний коментар / відп. ред. Є.Л. Стрельцов. Харків: Одіссей, 2012. 904 с.

9. Науково-практичний коментар Кримінального кодексу України / за заг. ред. О.М. Джужі, А.В. Савченка, В.В. Чернєя. Київ: Юрінком Інтер, 2016. 1064 c.

10. Науково-практичний коментар Кримінального кодексу України / за ред. М.І. Мельника, М.І. Хавронюка. Київ: Юридична думка, 2012. $1316 \mathrm{c}$.

11. Науково-практичний коментар до Кримінального кодексу України: у 2 т. Т. 1 / за заг. ред. П.П. Андрушка, В.Г. Гончаренка, Є.В. Фесенка. Київ: Алерта; КНТ; ЦУЛ, 2009. 964 с.

12. Кримінальне право (Особлива частина): підручник / за ред. О.О. Дудорова, Є.О. Письменського. Київ: ВД «Дакор», 2013. $786 \mathrm{c}$.

13. Андрушко А.В. Зарубіжний досвід регламентації кримінальної відповідальності за підміну дитини. Держава та регіони. Серія: Право. 2018. № 4 (62). С. 99-105.

14. Белова О.І. Кримінально-правова характеристика системи злочинів проти сім'ї та неповнолітніх: автореф. дис. ... канд. юрид. наук: 12.00 .08 . Київ, 2007. 18 с.
15. Гальцова В.В. До проблеми об'єкта і системи злочинів проти сім’ї, прав та інтересів неповнолітніх. Проблеми законності. 2014. Вип. 125. С. 103-201.

16. Євтєєва Д.П. До питання виділення злочинів проти сім'ї в окремий розділ КК України. Питання боротьби зі злочинністю. 2014. Вип. 27. С. $72-81$.

17. Лихова С.Я. Злочини у сфері реалізації громадянських, політичних та соціальних прав і свобод людини і громадянина (розділ $\mathrm{V}$ Особливої частини КК України): монографія. Київ: ВПЦ «Київський університет», 2006. $573 \mathrm{c}$.

18. Гальцова В.В. Проблеми кримінально-правової політики у сфеpi боротьби зі злочинами проти сім'ї, прав та законних інтересів неповнолітніх. Політика в сфері боротьби зі злочинністю: матеріали Всеукраїнської науково-практичної конференції (1-2 березня 2013 р., м. Івано-Франківськ). Івано-Франківськ, 2013. С. 98-101.

19. Дудоров О.О., Хавронюк М.І. Кримінальне право: навчальний посібник / за заг. ред. М.І. Хавронюка. Київ: Ваіте, 2014. 944 с.

20. Бандурка І.О. Чи потрібен в Особливій частині КК України окремий розділ про злочини проти сім'ї та дітей? Актуальні проблеми кримінальної відповідальності: матеріали міжнар. наук.-практ. конф., 10-11 жовт. 2013 р. / редкол.: В.Я. Тацій (голов. ред.), В.І. Борисов (заст. голов. ред.) та ін. Харків: Право, 2013. C. $399-401$.

21. Пудовочкин Ю. Уголовная ответственность за подмену ребенка. Уголовное право. 2001. № 3. С. 43-44.

22. Кримінальне право України: Особлива частина: підручник / за заг. ред. Є.Л. Стрельцова. Харків: Одіссей, 2009. 496 с.

23. Савельева В. Похищение или подмен ребенка. Советская юстиция. 1988. № 7. С. 28-29.

24. Почивалова К.Н. Проблемы законодательной техники и правоприменительной деятельности, связанные с преступлениями против семьи и несовершеннолетних: автореф. дисс. ... канд. юрид. наук: 12.00.08. Ростов-на-Дону, 2004. 31 c.

25. Пухтий Е.Е. Преступления против семьи и несовершеннолетних: вопросы техники конструирования составов и дифференциации ответственности: автореф. дисс. ... канд. юрид. наук: 12.00.08. Казань, 2004. 25 c.

26. Гуль Н.В. Конституционное право на защиту семьи в уголовном законодательстве России: автореф. дисс. ... канд. юрид. наук: 12.00.08. Москва, 2009. 27 с.

27. Кваліфікація злочинів, підслідних органам внутрішніх справ: навчальний посібник / за заг. ред. В.В. Коваленка; за наук. ред. О.М. Джужи та А.В. Савченка. Київ: Атіка, 2011. 648 с.

28. Коржанський М.Й. Кваліфікація злочинів: навчальний посібник. Київ: Атіка, 2007. 592 с.

29. Ткаченко В.И. Преступления против личности. Учебное пособие. Москва: ВЮЗИ, 1981.77 с.

30. Науково-практичний коментар до Кримінального кодексу України / відп. ред. С.С. Яценко. Київ: А.С.К., 2006. 848 с.

31. Романчук I.О. Кримінально-правова характеристика потерпілого від злочину, передбаченого статтею 148 Кримінального кодексу України. Вісник Кримінологічної асоціації України. 2015. № 3 (11). C. 209-222.

32. Акиев А.Р. Уголовная ответственность за посягательства на интересы семьи: автореф. дисс. ... канд. юрид. наук: 12.00.08. Омск, 2017. $22 \mathrm{c}$.

33. Шищенко Е.А., Палий О.И. Актуальные уголовно-правовые вопросы квалификации подмены ребенка. Научный журнал КубГАУ. 2016. № 118 (04). C. 1-19. URL: http://ej.kubagro.ru/2016/04/ pdf/07.pdf

34. Лохвицкій А. Курсь русскаго уголовнаго права. Второе исправленное и дополненное изданіе, сведенное съ кассаціонными рьшеніями. СПб.: Скоропечатня Ю.О. Шрейера, 1871. 704+VI c. 
35. Колмакова О.С. Преступления, посягающие на права ребенка в сфере семейных отношений: автореф. дисс. ... канд. юрид. наук: 12.00.08. Москва, 2015. 25 с.

36. Великий тлумачний словник сучасної української мови (з дод. і допов.) / уклад. і голов. ред. В.Т. Бусел. Київ; Ірпінь: ВТФ «Перун», 2005. 1728 c.

37. Колмакова О.С. Преступления, посягающие на права ребенка в сфере семейных отношений: дисс. ... канд. юрид. наук: 12.00.08. Москва, 2014. 197 с.

38. Хатуев В.Б. Уголовно-правовая охрана беременных женщин, малолетних, беззащитных и беспомощных лиц и лиц, находящихся в зависимости от виновного: дисс. ... канд. юрид. наук: 12.00.08. Москва, 2004. 189 с

39. Гулякевич Д.Л. Уголовно-правовая охрана ребенка в Республике Беларусь: дисс. ... канд. юрид. наук: 12.00.08. Москва, 2015. $266 \mathrm{c}$

40. Акиев А.Р. Уголовная ответственность за посягательства на интересы семьи: дисс. ... канд. юрид. наук: 12.00.08. Омск, 2017. $214 \mathrm{c}$

41. Ободовський О.В. Триваючі злочини у кримінальному праві України: монографія. Одеса: Юридична література, 2016. 256 с.

42. Гулякевич Д.Л. Уголовно-правовая охрана ребенка в Республике Беларусь: автореф. дисс. ... канд. юрид. наук: 12.00.08. Москва, 2015. $44 \mathrm{c}$.

43. Даценко Є.В. Суб'єктивна сторона підміни дитини за кримінальним законодавством України. Науковий вісник Херсонського дер- жавного університету. Серія Юридичні науки. 2014. Випуск 5-2. Том 1. С. 67-70.

44. Решетникова Г.А. Уголовно-правовая охрана семьи и несовершеннолетних: автореф. дисс. ... канд. юрид. наук: 12.00.08. Москва, $2005.37 \mathrm{c}$.

Андрушко А. В. Проблемы уголовной ответственности за подмену ребенка

Аннотация. В статье на основании анализа отечественного и зарубежного законодательства и научной литературы проанализированы недостатки действующей редакции ст. 148 Уголовного кодекса Украины, предусматривающей ответственность за подмену ребенка, и предложены возможные пути ее усовершенствования.

Ключевые слова: преступления против свободы, чести и достоинства личности; преступления против семьи и несовершеннолетних, подмена ребенка.

Andrushko A. Issues of the Criminal Liability for Substitution of a Child

Summary. The paper reviews on national and foreign legislation to analyze shortcomings of the current version of the article 148 of the Criminal Code of Ukraine which provides for liability for substitution of a child. The paper suggests possible ways to improve the respective article.

Key words: crimes against liberty, honor and dignity; crimes against family and minors; substitution of a child. 